\title{
English Nominal Clauses: Analyzing the Translation of Subordinate wh - Interrogative Clauses and Infinitive wh - Clauses in Azeri
}

\author{
Parisa Farrokh (Corresponding author) \\ English Translation Department, Lahijan Branch \\ Islamic Azad University, Lahijan, Iran \\ E-mail: p_farrokh@Yahoo.com \\ Kambiz Mahmoodzadeh \\ The Department of English Translation Studies \\ Allameh Tabatabai University, Tehran, Iran
}

Received: February 12, 2012

Accepted: April 9, 2012

Online Published: June 15, 2012

doi:10.5430/elr.v1n1p137

URL: http://dx.doi.org/10.5430/elr.v1n1p137

\begin{abstract}
This paper considers the Azeri translation of English nominal clauses with subordinate wh -interrogative clauses in complex sentences. Moreover, in this research, infinitive wh - clauses have been studied. Based on Quirk et al $\mathrm{s}$ classification of nominal clauses (clauses approximating in function noun phrases), they fall into six major categories: That -clause or subordinate declarative clauses, Subordinate interrogative clauses, Subordinate exclamative clauses, Nominal relative clauses, To - infinitive clauses and Ing clauses. An infinitive wh - clause can be formed with all wh -words. The infinitive clause has an obligational sense .In this paper, the data are drawn from studies based on the English - Azeri translated fictions. According to the results of the present study, $78 \%$ of these sentences in Azeri, translated as simple sentences involving verbal combinations, $12 \%$ translated as simple sentences without verbal combinations, $6 \%$ translated as complex sentences and $4 \%$ translated as compound sentences. Regarding the structures involving infinitive construction, the findings indicate that $68 \%$ translated as simple sentences consisting verbal combinations, and $32 \%$ translated as complex sentences. It can be said that, in Azeri, there is a tendency of using simple sentences instead of compound or complex ones. The results of this research also show that there are some mistranslations regarding the nominal clauses involving both wh -interrogative and infinitive constructions, due to ignoring of the "obligational sense of these clauses in Azeri translation, the percentage of these mistranslations is $86 \%$. In this research, the most frequent wh -interrogative word used in original texts, is "what" in 32 sentences and the least one, is "whom" in 7 sentences, in addition, the most frequent wh - interrogative word used in subordinates involving both wh - words and infinitive construction in original texts is "how" with the percentage of $53 \%$ and the least one is "where" with the percentage $11 \%$.
\end{abstract}

Keywords: Translation, Translator, Linguistics, Complex Sentences, Nominal Clauses

\section{Introduction}

Translation is an activity of increasingly vital importance in the educational, political, economic and cultural fields of human endeavors. Translation is a complex process beset by several difficulties and many problems, yet at the same time it has a wide scope with almost unlimited applications and prospects. Newmark defines translation as the attempt to produce approximate equivalence or respectable synonymy between two chunks of different languages on various levels of which two main ones are thought and linguistic form. Newmark adds that translation is partly an exercise in the art of writing as well as a field of comparative applied linguistics (1988,p.26). Newmark believes that grammatical meaning is more significant, less precise, more general and sometimes more elusive than lexical meaning (ibid). Since syntactic differences existing among languages may cause problem in translation, here it seems necessary to mention some characteristics of the Azeri language generally, which differ from English and should be considered in order to produce an acceptable translation. The Azeri language which is also known as Azeri, Azeri Turkish and Azerbaijani, is the Republic of Azerbaijan's official language, though some dialects of the language are spoken in several parts of Iran. The Azeri language can be heard in parts of eastern Turkey, northern Iraq, and in 
southeastern area of the Republic of Georgia. Worldwide, there are about 27 million native speakers of this language. The Azeri language is derived from the Oghuz family of language and linguistically, it is most closely related to Turkish, Persian and Arabic. As part of the Oghuz family of languages, it was brought from central Asia by Seljuk Turks and in the Middle East it was greatly influenced by the vocabulary and grammar of Persian and Arabic. Eventually, it replaced Tat, old Azeri and Middle Persian in Iran and became the most dominant language in a multi - lingual area by the 1500s. Regarding the grammar of Azeri, it can be said that it is an agglutinative language and frequently used affixes and specifically suffixes - Most of them indicate the grammatical function of the word. Word order in Azeri is generally subject - object - verb as in Korean and Latin but unlike English. In more complex sentences, the basic rule is that the qualifier precedes the qualified; this principle includes, as an important special case, the participial modifiers. The definite precedes the indefinite. It is possible to alter the word order to stress the importance of a certain word or phrase. The main rule is that the word before the verb has the stress without exception. Moreover as Azeri is a pro-drop language, the subject may not be mentioned in the sentence. This research focuses on the analysis of English complex sentences with nominal subordinate clauses which involve both wh - interrogative clauses and infinitive construction and their translation in the Azeri language. The importance of this research is showing some methods for translating of these sentences into the Azeri language, due to existing syntactic peculiarities and differences between languages which may cause some problems in the process of translating. The underlying assumption of this research is that the translator must have enough knowledge and information about the structures of English and Azeri while translating these sentences in order to translate effectively. Since the Azeri language does not have such complexity - packaged constructions, the Azeri learners, and translators find it difficult to cope with these structures which are widely used in English writing. To this end English fictions are studied to identify those structures in English and their Azeri equivalents. In this relation the following research questions have been formulated: How are English nominal clauses involving subordinate wh interrogative clauses translated into Azeri?How are English nominal clauses involving both subordinate wh interrogative clause and infinitive construction translated into Azeri? Are these structures translated as complex sentences in Azeri language? What are the most frequent wh -interrogative words found in original texts?

\section{Translation and Translator}

Translation deals with language. As language is a means of communication, so does the function of translation. Nida (1981, p.12) states that translation means communication because it has three essential elements to form a process of communication. The three essential elements are source, message and the receptor, and these elements must be found in all communication activities. So, it can be said that translation is the medium of the source language and target language. We transform the meaning in source language in the form of target language by translation, so the renders in the target language understand the meaning in the source language. Successful translating involves one of the most complex intellectual challenges known to mankind. Moreover, in our present world, the need for extensive, accurate and effective communication between those using different languages, gives the translator a position of new and strategic importance (Nida, 1964, p. 155). Therefore translating from one language into another language is a complicated task. There are many factors that should be considered in the process of translation in order to make translation result be appropriate to be comprehended. Based on Catford's idea (1965) translation is the replacement of textual material in one language (source language) by equivalent textual material in another language (target language). Larson (1984) believes that translation consists of studying the lexicon, grammatical structure which appropriate in the receptor language and its cultural context, i.e." translating consists of reproducing in the receptor language. The closest natural equivalent of the source language message, first interms of meaning and secondly interms of style". Newmark says that translation is rendering the meaning of a text into another language in the way that the author intended the text (1988, p.73).

In translation, the translator possesses a satisfactory knowledge of the source language. He must understand not only obvious content of message but also, the subtleties of the meaning, the significant emotive values of words, and stylistic features which determine the flavor of the message. Even more important that knowledge of the resources of the language is a control of the receptor language. (Nida, 1964, p.150).

Therefore, a translator must have reliable knowledge and experience in this field. As a communicator, moreover, the knowledge and skills related to all communicators have to be possessed. He has to access the target language knowledge, text type knowledge, source language knowledge, subject area (real world) knowledge and cultural knowledge (Bell, 1991, p.36). 
Generally, in translating, it is important to ensure the surface meaning of the two languages in translation, are approximately similar and at the same time to ensure that the structure of the source language preserved as well as possible but not so closely that the target language structures will be seriously distorted.

\section{Linguistics}

Many researchers have still doubts about the importance of linguistics in translations studies which is also reflected in the majority of scholarly papers devoted to the subject. The linguistic relevance of information structure in the case of translation is even more evident if Azeri and a language such as English are involved. Azeri is a free word order language, as mentioned in introduction, in which grammatical structure is largely determined by the articulation in theme (logical subject) and rheme (logical predicate), whereas English does not permit much variation in word order, and syntactic structure is defined in terms of grammatical subject and grammatical predicate. This fact alone has important consequences for the theory and practice of translation. In addition, some word order variation in the Azeri language is due to a second type of articulation (which may, but need not coincide with the first one), which concerns information structure proper, i.e. distribution of known and new information in the sentence and its structural consequences. So linguistics plays an important role in the investigation of the joint functioning of two languages, i.e. "the translational behavior of languages". Dynamic contrasts are differences in encoding strategies characteristic of different languages; which become manifest only when these languages clash in the process of translation and also, information structure is one such domain where drastic dynamic contrasts in encoding may be encountered. The linguistic description of contrasting structures is indespensable for adequate translation. Regarding the recognition of the importance of context, it is quite clear that we normally do not translate sentences in isolation but sentences which are part of a larger text or discourse. Klaudy points out research into the translational behavior of languages and the decision making and problem solving strategies behind translational operations may result in a systemic translation oriented description of various language pairs. It is an adequate description of the linguistic structure of languages. In addition to descriptive and theoretical linguistics, translation studies may also profit from insights gained in sociolinguistics and psycholinguistics. klaudy (1981) argues that the translator mediates not only between two languages but also between two cultures. He must thus have certain ideas about the source language society and the target language society, which need not always be very explicit. Sociolinguistics attempts to reveal the relationship between language and society independently of translation and provide scientifically well - founded descriptions of this relationship. In this way, sociolinguistics may contribute to the clarification of the basis of the translators' decisions. Psycholinguistics may offer an explanation of how the translation process works. Klaudy reports, among other things, on experiments which have tried to find out whether or not it is possible to listen and speak simultaneously. Some of the results seem to indicate that simultaneous interpreters do not listen and speak at the same time, but they alternate between these two activities, using the pauses of the speaker as well as their own pauses (ibid).

In sum, then, socio - and psycholinguistics, too, are important branches of research for translation studies. As translators, we must not only know what we are doing but also why we are doing something in the way we are doing it (ibid).

Therefore, the importance of linguistics in translation studies is obvious and clear.

\section{Complex Sentence}

Complex sentences are widely used in English writing and specially literary works. Since in literary work the writer expresses himself in many kinds of sentences and making complex sentences is more challenging of the very large variety of clauses signals to choose from many combinations.

Complex sentences can be used to judge whether a work is written in a good way or not. By which, the accuracy and variety of the work can be known. Complex sentences are the best means of eliminating choppy sentences and giving accuracy of literary work. It will not be satisfied until he has at down the number of simple or compound sentences and increase the number of complex sentences. (Fauzanah, 2009, p.15).

To make his writing more accurate and everything equal, a writer will build his main idea into part of the sentence and tuck the detail into clause, in other words, he writes more complex sentences. Moreover, the using of more complex sentences in work, does not show the dullness of the sentences because of the variety of the sentences in its paragraphs and subordinate clauses, on the other hand, expresses the relations of the writer's ideas.

\section{Complex Sentences in English}

In English, sentences are either simple or multiple. A simple sentence consists of a single independent clause. A Multiple sentences contains one or more clauses as its immediate constituents. It is either compound or complex. In a 
compound sentence the immediate constituents are two or more coordinate clauses therefore, the clauses of a compound sentence provide classic instances of a paratactic relationship that is they have equivalent function. (Quirk et al, 1985, p.987). In a complex sentence, one or more of its element, such as direct object, adverbial and etc are realized by a subordinate clause. A complex sentence is like a simple sentence in which it consists of only one main clause, but unlike a simple sentence, it has one or more subordinate clauses functioning as element of the sentence. Subordination is an asymmetrical relation: the sentence and its subordinate clauses are in a hypotactic relationship that is they form a hierarchy in which the subordinate clause is a consistent of the sentence as a whole (ibid).

On the basis of their potential functions, several major categories of subordinate clauses are distinguished: Nominal, Relative, Adverbial and Comparative.

Since the study of subordinate wh - interrogative clauses is the aim of this research which are subcategorized in nominal clauses, here the syntactic and semantic function of nominal clauses are mentioned briefly.

Nominal clauses (clauses approximating in function noun phrases) fall into six major categories: That -clause or subordinate declarative clauses, Subordinate interrogative clauses, Subordinate exclamative clauses, Nominal relative clauses, To - infinitive clauses and Ing clauses. (Quirk et al, 1985, p.1049).

\section{Subordinate wh -interrogative Clauses}

Subordinate wh - interrogative clauses occur in the whole range of functions available to the nominal that -clause and in addition may function as prepositional complement: for example:

How the book will sell depends on the reviewers. subject

I can't imagine what they want with your address. direct object

The problem is who will water my plants when I am away. subject complement

Your original question, why he did not report it to the police earlier, has not yet been answered.

I am not sure which she prefers. appositive adjectival complementation

They did not consult us on whose names should be put forward. prepositional complement

These subordinate clauses resemble wh -questions semantically in that they leave a gap of unknown information, represented by the wh-element. An infinitive wh - clause can be formed with all wh -words, though instances with "why" are rare. The infinitive clause has an obligational sense (ibid). For example:

I don't know what to say: what I should say

I'm wondering where to put my coat: where I should put my coat.

As mentioned, in this research, English subordinate wh -interrogative and infinitive wh -clauses have been investigated.

\section{Complex Sentences in Azeri}

In Azeri, a sentence can be either simple or complex by its structure. (Habibli, 2008, p.241). Simple sentences are divided into four types according to their purpose and intonation: Narrative sentences, Imperative sentences, Interrogative sentences and exclamatory sentences. The sentence that consists of two or more sentences is called a complex sentence. In Azeri, there are two types of the complex sentences: compound sentence (Tábesiz Mürəkkəb cümlə) and complex sentence with one or more subordinate clauses (Tabeli Mürəkkəb cümlə). Like English, in Azeri also, there is one main clause (Baş cümlə) and one or more dependent or subordinate clauses (Budaq cümlə). For example: Mən bilmirəmki, o sizin suallınıza necə cavab verdi.

I do not know how he answered your question

Semantically, based on the meaning of wh -words used in subordinate clauses, they are categorized; such as; time subordinate clauses (zaman budaq cümlə) or reason subordinate clauses (səbəb budaq cümlə) and etc.

It is necessary to mention that in Azeri instead of wh -interrogative words used in subordinations, some words and combinations are used and called connective words (bağlayıcılar). 
Syntactically connectives classified into two groups: coordinate connectives ( $\mathrm{Ta}$ - besiz bağlayıcılar) and subordinate connectives (Tabeli bağlayıctlar). In contrast to compound sentences, in which coordinate connectives are used like və (and), ya (or), Lakin (but) and so on, in complex sentences subordinate connectives are used, such as hara (where), necə (why), kimi/ kimə (whom), kim (who) and etc. Therefore, in subordinate wh - interrogative clauses, in Azeri, wh -words, are replaced by subordinate connectives or tabeli baglayıctlar (Rosta mova, 2010).

\section{Research Method}

The purpose of this study is to investigate and analyze Azeri translations of English subordinate wh - interrogative clauses and infinitive wh - clauses. This research deals with the analysis of data in order to study Azeri translations of English complex sentences, subordinate wh -interrogative clauses, wh - words used in subordinate clauses, infinitive used in subordinate wh - interrogative clauses. Moreover, finding the most frequent "wh -words" used in these two types of structures in original texts.

\section{Materials}

The material chosen for analysis are English fictions which involve the novels of "For whom the Bell Tolls" written by Hemingway, "The Alchemist" and "By the River Piedra I Sat Down and Wept", written by Coelho and Joyce's Dubliners (short stories). 200 subordinate wh - interrogative clauses, which 100 sentences involving infinitive constructions, along with their translations into Azeri token from Hajiyev Qojabayli (2006), Aslanlı (2011) and Nijat (2011) have been analyzed.

\section{Procedures}

The data classified into two main categories: subordinate wh - interrogative clauses and infinitive wh - clauses.

Subordinate wh - interrogative clauses translated as simple sentences involving verb combinations.

* I don't know even what alchemy is.

Mən kimyagərlyin nə demək olduğunu belə bilmirəm.

* I read only what the birds wanted to tell me.

mən yalnız quşların anlat maq istədikləri şeyi oxudum.

* The camel driver understood what the boy was saying.

Cavan oğlanIn ona dediyi şeyi başa düşürdü.

* She couldn't hear what Pilar was saying.

O, Piların nə danışdı̆̆ını eştitmirdi.

* You will show me when we get there.

Düşərgəyə çatanda göstərərsən.

* I don't know who is prepared to stand that.

Buna kimin tab gətirə biləcəyini bilmirəm.

* You know why we didn't kill them.

sən onları nə üçün öldürmədiyimizi bilirsən.

* He was repeating something which he had learned by heart.

$\mathrm{O}$, əzbər bildiyi ifaddələri təkrar edir.

* I don't know where he is posted.

Poçt üçün harda yer seçdiyini bilmirəm.

Subordinate wh - interrogative clauses translated as simple sentences without verb combinations.

*I give you what you need.

Sənə hər şey verirəm.

* He understood why the owner of the bar had been so upset.

Qəhvəçinin ümidsiz cəhdlərini indi anayırdı.

Subordinate wh - interrogative clauses translated as complex sentences. 
* I don't know why I worried about it before.

bilmirəm nə ücün bu məni əvvəllər çox təşvişə salıdı.

* No one know how he achieved the stern task of living.

Heç kim bilmirdi ki o yaşamaq vasitələrini hansı yolla əldə edir.

\section{Subordinate wh - interrogative clauses translated as compound sentences.}

* His mother was a clever woman whom he always loved.

Onun anas I ağıllı idi və o anasını çox sevirdi.

* we have to turn a question why the man cannot go with man again though it is the question of millenniums.

Niyə insane insanle yola getmir, deyə millərin arxasından gələn suala dönməyə məcbur oluruq.

Subordinate wh - interrogative clauses and infinitive construction translated as simple sentences involving verb combinations.

* You don't know how to continue the conversation.

söhbət necə davam etdirəcəyiniz bilməzsiniz.

* He teaches people how to live.

$\mathrm{O}$ adamlara necə yaşamağı öyrədir.

Subordinate wh - interrogative clause and infinitive construction translated as complex sentences.

* I didn't know what to answer.

Bilmədim ki necə cavab verim.

* Juliet didn't know what to do.

Gülyetada bilmir ki nə etməlidir.

\section{Data Findings}

In this research there are two main categories, namely, subordinate wh - interrogative clauses and subordinate involving both wh - words and infinitive. Analyzing 100 data related to the Azeri translation of English subordinate wh - interrogative clauses shows that most of them in Azeri are translated as simple sentences involving verbal combinations with the percentage of $78 \%$ and some translated as simple sentences without verbal combinations with the percentage of $12 \%$.

Moreover, these structures, in Azeri, have been translated as complex sentence with the percentage of $6 \%$ and as compound sentences with the percentage of $4 \%$ (Table 1 ).

According to table (2), it has been cleared that $68 \%$ English subordinates involving both wh - words and infinitive translated as simple sentences involving verbal combinations and $32 \%$ translated as complex sentences. Table (3) indicates the percentage of errors of the mistranslation of English subordinates involving both wh-words and infinitive in Azeri, that is $86 \%$.

Based on table (4), it will be understood that the most frequent wh - word found in subordinate wh - interrogative clauses of original texts is "what" with the percentage of $32 \%$ and the least one is "whom" with the percentage of $7 \%$.

According to findings of this research, the most frequent wh - word used in subordinates involving both wh - words and infinitive construction in original texts, is "how" with the percentage of $53 \%$ and wh - word "where" with the least one, $11 \%$.

\section{Discussion and Conclusion}

Based on 200 data, it has been cleared that in Azeri, English subordinate wh - interrogative clauses and subordinates involving both wh - words and infinitive construction, are translated as simple sentences consisting verbal combinations.

Here it seems necessary to mention that verbal combinations in Azeri, are generally three types: verb conjunctions (Feli bağlama) which are some suffixes added to the verb and semantically expressing notions like time, manner, reason and etc. For example, "Düşərgəyə çatanda göstərərsən".

$$
\text { anda } \stackrel{\downarrow}{=} \text { feli bağlama }
$$


Some verb conjunctions' suffixes are - anda, əndə, araq, ərək, diqda, dikdə, and so on. Another verbal combination is participle (Feli Sifət), which involve some suffixes added to the verb, functioning both like verb and adjective.

Suffixes like acaq, əcək, dıq, dik, duq, dük, acaq, əcək ,... are a number of participle making suffixes. In the sentence, "Döyüş̧ə özümü necə aparacağımı bilmirəm".

acağ in "aparacağım I" named as participle making suffix. The word regarded as particple or Feli sifət.

The last verbal combination is verb - noun combinations.

They are also made by adding some suffixes such as

- a-a- , -ə-ə, -ar, iyi, and ets. These combinations functioning both as the verb and noun, such as: cavan oğlanın ona dediyi şeyi başa düşürdü".

verb $\stackrel{\downarrow}{\downarrow}$ noun

It should be noted that "participle" (Feli sifat) is the most frequent construction found in Azeri translation of subordinate wh - interrogative clauses and subordinates consisting both wh - words and infinitive construction. Generally it can be concluded that these complex sentences are translated as simple sentences and there is a tendency in Azeri, that is using of simple sentences involving verbal combinations.

These structures are used for translating of majority of English sentences such as complex sentences. Regarding the subordinates involving both wh - words and infinitive construction, which have the obligational sense, it should be said that in the Azeri translation of these structures, the meaning of them has not been considered and majority of translated sentences do not express the obligational sense. For example the sentence "I learned how to care for sheep" translated as "Qoyunlara baxmağı bilirəm", which should be translated as " Qoyunlara necə baxmaliyəniyə, bilirəm", because the suffix "mal" in the verb "baxmaliyəniyə" shows the obligation sense in Azeri. Another important point in Azeri translation of these complex sentences, is that unlike English, subordinate clauses come before main clause and the verb of subordinate clauses translated as verbal combination and the verb of main clause regarded as the main verb of the sentence. In addition, the infinitive construction is not translated as infinitive in Azeri. Based on findings of this research, it has been translated as verbal combinations specially verb conjunctions form (Feli bağlama).

As mentioned earlier, in translation, translator is transferring meaning of the source language in the form of target language. Moreover paying attention to the structure of the source language is necessary, and should be preserved as well as possible but not so closely that target language structures will be seriously distorted. Therefore translation is always more than simply writing in the sense of putting words to paper. It is suggested that in the literature of translation studies, in translation classrooms even in language learning classes, students and learners compare and contrast translation with their originals. It is useful for language learning, translation, education, lexicography, finding equivalents for source language expressions, terms, structures and so on.(Farrokh,2011,p.79). It is hoped that the results of the research may be used as additional information for the teachers, especially in teaching English grammar and translation courses. Also, the results may help Azerbaijanian translators, English learners and translator trainees for being able to provide the translation of English subordinate wh- interrogative clauses and subordinate involving both wh- clause and infinitive construction.

\section{References}

Aslani, A. (2011). By the river, Piedra I sat down and wept. (pp.5 - 96). Baku: Ghanun Publication.

Bell, R. (1991). The Nature of translation.Frunkfort am Main: Peter Lang.

Catford, J.C. (1965). A Liguistic theory of translation. (pp. 33-75). An essay in applied linguistics. Oxford: Oxford University.

Farrokh, P. (2011). The Equivalence and Shift in the Persian Translation of English Complex Sentences with wh-Subordinate Clauses. English Language and Literature Studies Vol. 1, No. 2. URL: http://dx.doi.org/10.5539/ells.

Fauzanah, R. (2009). A Translation analysis of complex sentences in novel "The Scarlet Letters" and its translation. Research paper for B. A degree. Indonesia: Muhammadaiyh University of Surakarta.

Habibli, R. (2008). Azeri Language. Baku: Baku state University Publication.

Hajiyev, H. (2006). For Whom the Bell Tolls. (pp. 27 - 290). Baku: Avrasiya Press.

Klaudy, k. (1981). Translation and information structure. (pp. 42 - 46). Murica: Edutec, CAM.

Larson, M.L. (1997). Meaning - based translation. (pp . 36-41).University press of America, Inc. 
Newmark, P. (1988). A Text book of translation. London and NewYork: Perntice Hall International.

Nida, E.A. (1975). Toward a science of translating: with special reference to principles and procedures involved in Bible translation (2nd ed). Leiden. E.J.Brill.

Nijat, A. (2011). Dubbliners. (pp.27 - 307) Baku: Ghanun Publication.

Qojabayli, N. (2006). The Alchemist. (pp . 5- 122). Baku: Chinar Punlication.

Quirk, R. Greenbaum, S. , Leech, G,. \& Svartvik, S. (1987). A comprehensive grammar of the English language. (5th ed). London and NewYork: Longman.

Rostamova, T. (2010). The comparision of Azeri and Persian grammar . (pp. 312 - 317). Baku: Adiloghlu Publication.

Table 1. The translation of subordinate wh - interrogative clauses

\begin{tabular}{|l|l|l|}
\hline & Total & Percentage \\
\hline simple sentences involving verbal combinations & 78 & $78 \%$ \\
\hline simple sentences without verbal combinations & 12 & $12 \%$ \\
\hline complex sentences & 6 & $6 \%$ \\
\hline compound sentences & 4 & $4 \%$ \\
\hline
\end{tabular}

Table 2. The translation of subordinates involving both wh - clause and infinitive

\begin{tabular}{|l|l|l|}
\hline & Total & Percentage \\
\hline simple sentences involving verbal combinations & 68 & $68 \%$ \\
\hline complex sentences & 32 & $32 \%$ \\
\hline
\end{tabular}

Table 3. Mistranslation of subordinates involving wh - clause and infinitive

\begin{tabular}{|l|l|l|}
\hline & Total & Percentage \\
\hline ignoring of obligational meaning & 86 & $86 \%$ \\
\hline
\end{tabular}

Table 4. The frequency of wh - words in subordinates wh - interrogative clauses in original texts

\begin{tabular}{|l|l|l|}
\hline wh - words & Total & Percentage \\
\hline what & 32 & $32 \%$ \\
\hline how & 17 & $17 \%$ \\
\hline when & 15 & $15 \%$ \\
\hline where & 12 & $12 \%$ \\
\hline who & 9 & $9 \%$ \\
\hline why & 8 & $8 \%$ \\
\hline whom & 7 & $7 \%$ \\
\hline
\end{tabular}

Table 5. The frequency of wh - words in subordinates involving wh - clause and infinitive in original texts

\begin{tabular}{|l|l|l|}
\hline wh - words & Total & Percentage \\
\hline how & 53 & $53 \%$ \\
\hline what & 23 & $23 \%$ \\
\hline when & 13 & $13 \%$ \\
\hline where & 11 & $11 \%$ \\
\hline
\end{tabular}

